\title{
Family Coping Affects The Quality of Life Patients with Tuberculosis
}

\author{
Trisca Haprilianingtyas \\ Faculty of Nursing, Universitas Airlangga \\ Surabaya, Indonesia
}

\author{
Makhfudli \\ Faculty of Nursing Universitas Airlangga \\ Surabaya, Indonesa \\ Ika Nur Pratiwi \\ Faculty of Nursing, Universitas Airlangga \\ Surabaya, Indonesia \\ ikanurpratiwi@fkp.unair.ac.id
}

\begin{abstract}
Patients with Tuberculosis (Tb) often have high morbidity and low quality of life. Family coping was the essential part of patients' quality of life and may also give support to patients with Tb. Our study aimed to determine the correlation of family coping and quality of life in patients with Tuberculosis. This was a crosssectional study, the participants were selected purposively from primary health care (PHC) database and screened based on inclusion criteria; Aged 15-54 years, consented to study, and have completed intensive phase of $\mathrm{Tb}$ treatment. The quality of life was measure using WHOQOL-BREF questionnaire and coping capacity with F-COPES evaluation tools. The correlation coefficient was calculated using Pearson correlation test. From a total of 67 patients registered with $\mathrm{Tb}$ at the $\mathrm{PHC}, 34$ patients met inclusion criteria. Mean score of a family coping, and patients' quality of life were 77.05 and 68.73 respectively. Pearson product test showed significant relationships $(P<0.05)$ with strong correlation $(r=0.514)$ between the two variables. It can be concluded that family coping is positively correlated with the quality of life of a patient with pulmonary tuberculosis. Further research is needed to determine driving factors that can affect the quality of life of pulmonary tuberculosis.
\end{abstract}

Keywords: Tuberculosis, coping, quality of life

\section{INTRODUCTION}

Tuberculosis of Lung is still the leading infectious disease and has a major global public health impact.In Indonesia, treatment of Tuberculosis has shown improvement, yet the quality of life status of patients declined [1]. The decline was due to a physical health problem that has multiple effects on organ system. In the long term, the long duration of treatment and physical disturbance may affect psychological wellbeing, physical activity, and social relationships [2]. Several key factors including family support [3], and coping [4] play an important role in maintaining health status especially in patients with chronic disease.

Indonesia is the country with second largest cases of Tuberculosis after India, followed by Nigeria, Pakistan, China, and South Africa. In 2015, 1.020 thousand people had Tb [5]. It was estimated that new cases of Tuberculosis in Indonesia were 450,000 annually contributing to 8.8 million new cases worldwide [6].

In Surabaya city, there were 2,054 reported cases of Tuberculosis in 2014 from primary health care (PHC) with the Perak Timur PHC being the highest contributor with 190 cases (66 cases positive Ziehl Nielsen smear) followed by Kali Kedinding PHC [6].

We conducted a preliminary study in Perak Timur primary health care (PHC) in March 2016 on two patients and their families with Tuberculosis visiting Perak Timur PHC. The interview was exploring patients'satisfaction and general perception regarding their Tuberculosis treatment. The patients suggested that their disease reduces their daily activity and that taking long-term medication was a tedious and exhausting activity. They were also anxious and worried about having Tuberculosis, even though the cure rate of the disease was promising. Their family is concerned about the severity of disease, social impact of the disease, and disease transmission, this may compromise family support and cope with patients during their treatment period, and consequently, could alter the quality of life. In this study, we aimed to evaluate the relationships of a family coping of patients with Tuberculosis and their quality of life.

\section{METHODS}

The study was conducted between February and May 2016 at Perak Timur PHC in Surabaya city. The Independent variable of this research was family coping patients with tuberculosis and dependent variable was quality of life patients with tuberculosis. We purposively (based on researcher's judgment) recruited patients who have been confirmed to have Tuberculosis and were have completed intensive phase of Tuberculosis treatment, aged between 1554 years and were consented to participate. The inclusion criteria for patients' family to participate were Literate, Live in the same place/house with the patient (parents, siblings, or spouse) and Aged of more than 17 years old. 
TABLE I. PARTICIPANTS’ CHARACTERISTICS

\begin{tabular}{|c|c|c|c|}
\hline No. & Characteristics & n & $\%$ \\
\hline \multirow[t]{6}{*}{1.} & Age & & \\
\hline & $15-24$ year & 8 & 23.53 \\
\hline & 25-34 year & 10 & 29.41 \\
\hline & $35-44$ year & 9 & 26.47 \\
\hline & $45-55$ year & 7 & 20.59 \\
\hline & Total & 34 & 100.00 \\
\hline \multirow[t]{4}{*}{2.} & Gender & & \\
\hline & Male & 15 & 44.12 \\
\hline & Female & 19 & 54.88 \\
\hline & Total & 34 & 100.00 \\
\hline \multirow[t]{6}{*}{3.} & Education level Completed & & \\
\hline & Primary School & 8 & 23.53 \\
\hline & Secondary School & 14 & 41.18 \\
\hline & High School & 8 & 23.53 \\
\hline & Bachelor & 4 & 11.76 \\
\hline & Total & 34 & 100.00 \\
\hline \multirow[t]{7}{*}{4.} & Employment & & \\
\hline & Student & 5 & 14.71 \\
\hline & Unemployed & 11 & 32.35 \\
\hline & Labor worker & 7 & 20.59 \\
\hline & Government official & 1 & 2.94 \\
\hline & Self-employed & 10 & 29.41 \\
\hline & Total & 34 & 100.00 \\
\hline
\end{tabular}

TABLE II. FAMILY COPING RESULTS

\begin{tabular}{clc}
\hline No. & Coping Type & Total Score \\
\hline 1. & Social support & 653 \\
\hline 2. & Positive value & 885 \\
\hline 3. & Looking for spiritual support & 405 \\
\hline & & \\
\hline 4. & Mobilize family to seek help & 316 \\
\hline 5. & Passive value & 393 \\
\hline & Mean Score & 77.05 \\
\hline
\end{tabular}

The questionnaire used to measure the quality of life was WHO Quality of Life-BREF (WHOQOL-BREF) which consist of 23 favorable questions and three unfavorable questions. The questionnaire has five Likert-scale with acceptable validity $(r=0.89-0.95)$ and reliability $(R=0.66-$ 0.87) [7]. Family coping was evaluated using F-COPES (Family Crisis-Oriented Personal Evaluation Scale) which consist of 30 questions with five Likert-scale [8]

The study has been reviewed for ethical consideration of involving human subjects by Ethics Committee of Faculty of Nursing, Universitas Airlangga (Certificate number: 139/KEPK)

\section{RESULTS}

Based on the data of Perak Timur PHC, there were 67 patients that were actively visiting for Tuberculosis follow up. Of those, 34 patients consented and met the inclusion criteria. All patients have been confirmed to have positive Ziehl Nielsen smear of Tuberculosis bacteria.
TABLE III. QUALITY OF LIFE (QOL)

\begin{tabular}{llc}
\hline \multicolumn{1}{c}{ No. } & \multicolumn{1}{c}{ QoL Domain } & Total Score \\
\hline 1. & Physical wellbeing & 628 \\
\hline 2. & Psychological wellbeing & 624 \\
\hline 3. & Social relationships & 187 \\
\hline 4. & Environment & 711 \\
& Mean Score & 68.73 \\
\hline
\end{tabular}

TABLE IV. PEARSON CORELATION BETWEEN FAMIY COPING AND QUALITY OF LIFE

\begin{tabular}{|c|c|c|}
\hline & \multicolumn{2}{|c|}{ Quality of life } \\
\hline \multirow{2}{*}{ Family coping } & $\mathrm{r}$ & $\mathrm{P}$ \\
\hline & 0,514 & 0,001 \\
\hline
\end{tabular}

Table1. Shows demographics characteristics of recruited patients. Age distribution was similar in all age group with majority participants had latest education of secondary school and were mostly employed.

Family coping based on WHOQOL-BREF questionnaire was displayed in Table 2. The score range was 62 to 96 , and that there were several patients have score below the mean. FCOPES score of all participants also displayed on Table 3 ranging from 56 to 93 in each patient. Several patients also scored below the mean.

Pearson correlation test showed that the family coping has significant relationships to patients' quality of life with strong correlation $(\mathrm{r}=0.515, \mathrm{p}<0.05)$. It means that the stronger family coping and support, the higher quality of life patients could achieve.

\section{DISCUSSION}

Our study evaluated the relationships of family coping during Tuberculosis treatment period and the patients' quality of life. We found significant relationships with strong correlation between them. This was in line with Lindstrom theory [9] that quality of life is affected by family coping support, especially those who live immediately.

Most of the participants in this study responded that they would consult their close family when having a problem with their disease or other daily problems. Also, several respondents also revealed themselves of having low spiritual adherence.

In terms of quality of life, participants have generally low social relationships score. They were afraid of being abandoned of their community because of their contagious disease. They also inclined of giving "unsatisfactory" response to their living conditions especially for their house and surroundings, and thus this affect the score of environmental domain. Majority of participants also complained of having less leisure time to go on vacation.

\section{A. Family coping}

One that affects the quality of life of patients with tuberculosis is the presence of social support, Family is one of 
the social support close to the patient [10]. Similar study focusing on patients with cancer chemotherapy has been conducted [11]. The study suggested that one of the key factors of family coping during chemotherapy episodes were self-control. This was a self-convincing from family member to maintain support and accompaniment to patients and encourage patient's self-confidence to recover. The other factor was the adherence of family member to advise from medical and health professional such as comply with the treatment schedule and accompanying patients when visiting the doctor.

Family plays an important role in primary prevention of disease. It could reduce or even stop the risky behavior such as smoking, excessive alcohol consumption, and encourage individuals to have routine exercise. Family could motivate their family members in learning new ways achieving healthy life [12].

Individuals having disease have reciprocal relationships with their family. They could alter family interaction and wellbeing, while family support could affect individual's disease progression [4]. This because family often involve in decision making process including treatment choice, diagnosis, and recovery process [4].

Moya and colleagues in their study suggested that negative thinking could increase psychological stress, fear, and worsen disease condition. Patients with Tuberculosis often conceal their condition because they were afraid of being ignored or avoided by their peers. They, on the other hand, need support to recover, reduce anxiety, and thus improve wellbeing. The improvement of wellbeing means improvement of quality of life [2].

\section{B. Quality of Life}

Quality of life is an individual perception of one's position in life in the context of cultural and values where they live and its relation to goals, hopes, and the self-determined standard [13]. In WHOQOL-BREF, quality of life was divided into four key domains; physical wellbeing, psychological wellbeing, social relationships, and environmental aspect. Tuberculosis will affect all aspects of quality of life such as general health, somatic, psychological, spiritual and physical, social and role functions [14].

Study of patients with Tuberculosis in West Java, Indonesia, suggested that there was an association between social support and the improvement of patients' quality of life (Hastuti. 2014). The study also highlighted that social support could be a help from other people in patients' life and thus made them feel cared, respected, and loved.

Family with good coping often see a problem from its positive point of view [4]. Family coping will affect the patient's treatment behavior and will also affect the quality of life of patients [15]. Family member with good coping mechanism behaved relax and calm in facing the problem. They perceive that such behavior could help the diseased in their psychological aspect and reducing self-anxiety. They also seen the reality that one of their family member having cancer could gather them in the way they have rarely been before[11].

Maintaining quality of life is prudent in patients with Tuberculosis given that this infectious disease requires longterm treatment. The disease may also develop a progressive worsening and has wide range of physical, mental, social, and spiritual effects. Long-term and sustainable support is needed to prevent disease progression and thus improving quality of life. Several limitations in this study were the relatively small number of sample size, and the biases that may arise from recruitment methods and the nature of observational study.

\section{CONCLUSION}

There was a strong correlation between family coping capacity and quality of life of patients with Tuberculosis.

\section{REFERENCES}

[1] J. Brown, S. Capocci, C. Smith, S. Morris, I. Abubakar, and M. Lipman, "Health status and quality of life in tuberculosis," Int. J. Infect. Dis., vol. 32, pp. 68-75, Mar. 2015.

[2] et al. Hastuti I. D., "Hubungan Dukungan Sosial dengan Kualitas Hidup pada Penderita Tuberkulosis Paru di Balai Kesehatan kerja Masyarakat Provinsi Jawa Barat Tahun 2014," J. Bhakti Kencana Med. Vol.4, No.1 (Hlm. 58-63), 2014.

[3] Noorkasiani, "Sosiologi Keperawatan," in EGC, Jakarta, 2009.

[4] M. M. Friedman, "Buku Ajar Keperawatan Keluarga: Riset, Teori, dan Praktik," in EGC, Jakarta, 2010.

[5] "WHO | Global tuberculosis report 2016," World Health Organization, 2016.

[6] Dinas Kesehatan Kota Surabaya, Profil Kesehatan Kota Surabaya Tahun 2014. Surabaya: Dinas Kesehatan Kota Surabaya, 2014.

[7] A. Gholami, L. M. Jahromi, E. Zarei, and A. Dehghan, "Application of WHOQOL-BREF in measuring quality of life in health-care staff," Int. J. Prev. Med., vol. 4, no. 7, pp. 809-817, 2013.

[8] M. Pereira and M. Da Gracá Pereira, "Morbidity, family coping, burden and quality of life in cancer patients and caregivers," Psychooncology., vol. 23, pp. 297-298, 2014.

[9] King C. R. dan Pemela S. H., Quality of Life (From Nursing and Patient Perspectives). Canada: Jones \& Bartlett Learning ., 2012.

[10] C. A. Marra, F. Marra, V. C. Cox, A. Palepu, and J. M. Fitzgerald, "Factors influencing quality of life in patients with active tuberculosis," Health Qual. Life Outcomes, vol. 2, no. 58, pp. 1-10, 2004.

[11] F. Kharisma, "Respon dan Koping Keluarga terhadap Penderita Kanker Serviks yang Mendapat Kemoterapi di RSUD dr. Moewardi," Muhammadiyah University Surakarta, 2014.

[12] Friedman, Buku ajar keperawatan keluarga: Riset, Teori dan Praktek. Jakarta: EGC, 2010. 
[13] W. Unanue, V. L. Vignoles, H. Dittmar, and M. Vansteenkiste, "Life goals predict environmental behavior: Cross-cultural and longitudinal evidence," $J$. Environ. Psychol., vol. 46, pp. 10-22, 2016.

[14] N. N. Hansel, A. W. Wu, B. Chang, and G. B. Diette, "Quality of life in tuberculosis: Patient and provider perspectives," Qual. Life Res., vol. 13, no. 3, pp. 639-
652, Apr. 2004.

[15] P. D. Rachmawati, R. Ranuh, and Y. Arief, "MODEL PENGEMBANGAN PERILAKU IBU DALAM PEMENUHAN KEBUTUHAN ASAH, ASIH DAN ASUH ANAK LEUKEMIA," J. NERS, vol. 11, no. 1, p. 63, Apr. 2016. 